\title{
Small Intestine Cancer pNO TNM Finding v7
}

National Cancer Institute

\section{Source}

National Cancer Institute. Small Intestine Cancer pNO TNM Finding v7. NCI Thesaurus.

Code $C 89876$.

Small intestine cancer without regional lymph node metastasis. (from AJCC 7th Ed.) 